Oleh :

Rancang Bangun Pabrik Pengolahan Kulit Kelinci Menjadi Kulit Kelinci Berbulu Samak Krom Skala Kecil. Oleh : Ir. Harniniek, Ir. Titik Purwati Widowati

Penentuan Jumlah Riklim Maksimum Dalam Kompon Sol Plastik Ditinjau Dari Segi Tekno Ekonomi. Oleh : Susilowati., Sri Wahyuni., Sri Sukaeni

Penelitian Pengaruh Waktu Penekanan Dan Tekanan Terhadap Daya Rekat Lem Sintetis Untuk Kulit Sol Boks dan PVC. Oleh : Sunarso, Hs., Bambang Oetoyo

Abstract.

The object of this study is to obtain the differences glace leather properties made from

a. Sun dried goat skins

b. Wet salted goat skins

c. And preserved for 1,2 and 3 months successivelly, the curring and preservation of which is in accordance with BPK (KSI) method.

The sample observed is 18 sides goat skins which are taken from a slaughted - house in Yogyakarta.

9 side of those are preserved by sun drying and the rest is wet salted, preserved for 3 months is accordance with BPK / KSI method of preservation.

Out of the 1,2 and 3 moths preservation, 1 side of the dried and wet salted skins is taken and processed into glace leather according to $\mathrm{BPK}$ method with 2 replications.

The tanned leather then is subjected to organoleptic, physical and chemical analyses.

The study is carried out in 1 year.

The chemical and organoleptic data are obtaned from variance sub sample $(E<0,05)$ CRD factorial analyses.

Whereas the physical properties are analysed by variance sub sample $(\varepsilon<0,05)$ CRD factorial and Duncan's Test $(\xi<0,05)$.

The result of organoleptic analyses show that there is no different properties between glace leather mode from dried and wet salted goat skins $(\mathcal{E}<0,05)$ and the time of preservation used has no influence on them $(f<0,05)$

But there are differences on tensile strength and stretch properties between glace leather made from dried and wet salted skins ( $E<0,05$ ) and the time of preservation used influnces on them $(\varepsilon<0,05)$. 
Menurut Aten et al, ada 2 cara penggaraman yaitu :

enggaraman kering (dry salting).

enggaraman basah (wet salting).

tesa.

asil kulit jadi (kulit glase) dari kulit kambing yang diawet engan garam basah kualitasnya lebih tinggi dari pada yang asal dari kulit kambing yang diawet kering dengan sinar latahari.

da pengaruh lama penyimpanan terhadap kualitas kulit jadi (it glase) yang berasal dari kulit kambing yang diawet degan garam basah maupun yang berasal dari kulit kambing ang diawet kering dengan sinar matahari.

\section{CARA PENELITIAN}

Sampel yang digunakan dalam penelitian ini terdiri dari 9 bar kulit kambing kualitas I yang diawet dengan garam badan 9 lembar kulit kambing kualitas prima yang diawet ke- dengan sinar matahari, kulit tersebut di atas diambil dari toir (rumah potong hewan).

lit tersebut setelah diawet kemudian disimpan dengan lama ktu bervariasi yaitu : 1 bulan, 2 bulan dan 3 bulan.

ra pengawetan kulit dengan metoda BPK : Kulit kambing disihkan dari sisa daging dan gajih (lemak), kemudian di pen18 dengan pementangan di atas papan yang bagian tengahnya 18 dengan pementangan di atas papan

ian pertama yang dipakukan di atas papan pentangan adalah ekor, kemudian leher, sisi perut, kaki depan, belakang bagian-bagian lainnya dengan jarak antara dua paku lebil ang $10 \mathrm{~cm}$.

da pemakuan kulit tidak terlalu ketengah, tetapi dapat mena berat tarikan sehingga tidak sobek.

elah kulit rapi di atas papan pentangan, jemur di bawah simatahari.

ngeringan pada hari pertama dimulai pada jam 8.00 sampai n 11.00, pada hari kedua dimulai jam 09.00 sampai jam 12.00 jemur dan selanjutnya diangin-anginkan.

keempat dicabut dari pentangan, terus diracun dengan per ar air yang diperlukan.
Cara pengawetan dengan penggaraman, kulit kambing setelah dibersihkan dari sisa daging dan gajih (lemak) kemudian ditimbang, setelah itu masing-masing digarami dengan garam halus sebanyak $40 \%$ dar1 berat kulit.

Kuit pada bagıan daging ditaburi garam sampai rata.

Setelah itu dilipat bagian daging didalam dan ditumpuk diatas papan kemudian kulit disimpan.

Setelah satu bulan ambil 1 lembar kulit garaman dan 1 embar kulit kering disamak menjadi kulit glase dengan metoda BPK, replikasi 2 kali.

Seterusnya dilakukan pula pada tiap 3 lembar kulit garaman dan 3 lembar kulit kering setelah disimpan 2 bulan dan 3 builan. Sebelum disamak kulit mentah yang diawet dengan garam dan diawet keting, diperiksa dulu keadaannya, diamati baunya (mequnjukkan kebusukan/kerusakan atau tidak), dan dilihat keadaan bulunya yaitu rontok dan mudah dicabut atau tidak.

Hal ini perlu untuk melihat kulit mentah yang diawet tersebut, baru mulai atau sudah mengalami kerusakan atau belum.

Setelah menjadi kulit glase semua, kemudian dilakukan pengujian organoleptis, kekuatan tarik dan kemuluran.

* BPK = Balai Penelitian Barang Kulit.

\section{HASIL PENELITIAN DAN PEMBAHASAN}

1. Hasil penilaian kulit glase dari kulit garaman dan kulit kering, secara organoleptis (kuantitatif) secara panel.

Tabel *) : 1. Hasil Pemeriksaan kulit secara organoleptis.

\begin{tabular}{|c|c|c|c|c|c|c|}
\hline \multirow{4}{*}{$\begin{array}{l}\text { Bu- } \\
\text { Ian }\end{array}$} & \multicolumn{6}{|c|}{ Pengawetan } \\
\hline & \multicolumn{3}{|c|}{ Kering } & \multicolumn{3}{|c|}{ Garaman } \\
\hline & \multicolumn{3}{|c|}{ Replikasi } & \multicolumn{3}{|c|}{ Replikasi } \\
\hline & 1 & 2 & 3 & 1 & 2 & 3 \\
\hline $\begin{array}{l}1 . \\
2 . \\
3 .\end{array}$ & $\begin{array}{l}68 \\
57 \\
65\end{array}$ & $\begin{array}{l}65 \\
70 \\
68\end{array}$ & $\begin{array}{l}62 \\
57 \\
57\end{array}$ & $\begin{array}{l}69 \\
66 \\
64\end{array}$ & $\begin{array}{l}77 \\
60 \\
63\end{array}$ & $\begin{array}{l}65 \\
54 \\
63,30\end{array}$ \\
\hline
\end{tabular}


nalisa variance dapat dilihat sebagai berikut :

nalisa variance pemeriksaan kulit glase dari kulit garaman in kulit kering secara organoleptis.

\begin{tabular}{l|r|r|r|r|r}
\hline mber variasi & df & \multicolumn{1}{c|}{ SS } & MS & F hit & $\begin{array}{c}\text { F tab/ } \\
0,05\end{array}$ \\
\hline Kering dan & 1 & 2,005 & 2,005 & 0,0184 & 4,75 \\
garaman & 2 & 102,2433 & 51,1216 & 0,4679 & 3,89 \\
Penyimpanan & 2 & 14,1766 & 7,0883 & 0,0648 & 3,89 \\
Pengawetan X & 12 & 1310,8601 & 109,2383 & & \\
Penyimpanan & & & \\
Error
\end{tabular}

\section{eterangan :}

Tidak ada perbedaan antara kulit kering dan garaman ( $\mathrm{P}$ hit $<$ P tab 0,05).

Tidak ada pengaruh penyimpanan ( $P$ hit $<P$ tab 0,05).

Tidak ada interaksi penyimpanan maupun cara pengawetan ( $P$ hit $<P$ tab 0,05).

Data dari Studi Perbandingan mutu kulit jadi (finished leather) yang berasal dari kulit yang diawet dengan garam dan kulit yang diawet dengan sinar matahari.

Hasil pengujian kekuatan tarik $\left(\mathrm{kg} / \mathrm{cm}^{2}\right)$ kulit glase dari kulit kering dan kulit garaman.

abel *) : 2 Hasil pengujian kekuatan tarik kulit glase.

\begin{tabular}{|c|c|c|c|c|c}
\hline \multicolumn{5}{|c}{ Pengawetan } \\
\hline \multicolumn{3}{|c|}{ Kering } & \multicolumn{3}{c}{ Garaman } \\
\cline { 2 - 7 } & \multicolumn{3}{|c|}{ Replikasi } & \multicolumn{3}{c}{ Replikasi } \\
\hline 1 & 2 & 3 & 1 & 2 & 3 \\
\hline 240,00 & 286,71 & 282,05 & 276,68 & 273,33 & 293,78 \\
257,77 & 222,22 & 241,54 & 238,63 & 242,42 & 261,82 \\
205,00 & 156,34 & 159,34 & 237,50 & 220,28 & 233,33 \\
\hline
\end{tabular}

רalisa variance dapat dilihat sebagai berikut :

רalisa variance dari pengujian kekuatan tarik kulit glase dari lit kering dan kulit garaman

\begin{tabular}{l|r|r|r|r|r}
\hline Sumber varıasi & df & SS & MS & F hit & $\begin{array}{r}\text { F tab/ } \\
0,05\end{array}$ \\
\hline $\begin{array}{l}\text { - Pengawetan kering } \\
\text { dan garaman }\end{array}$ & 1 & 2.857 .932 & 2.837 .932 & 8.2555 & 2,75 \\
- Penyimpanan & 2 & 16.305 .878 & 8.152 .939 & 23.5506 & 3,89 \\
- Pengawetan X & 2 & 2.267 .729 & 1.133 .864 & 3.2752 & 3,89 \\
$\quad \begin{array}{l}\text { penyimpanan } \\
\text { - Error }\end{array}$ & 12 & 4.154 .242 & 346.186 & & \\
\hline
\end{tabular}

\section{Keterangan :}

- Ada perbedaan antara kulit kering dan kulit garaman ( $\mathrm{P}$ hit $>$ P tab 0,05).

- Ada pengaruh penyimpanan antara kulit kering dan kulit garaman ( $P$ hit $>P$ tab 0,05 ).

- Tidak ada interaksi antara penyimpanan dan perlakuan dari kulit yang diawet kering atau kulit yang diawet dengan garam (P hit < P tab 0,05).

*) Data dari : Studi perbandingan mutu kulit jadi (Finished leather) yang berasal dari kulit yang diawet dengan garam dan kulit yang diawet dengan sinar matahari.

Dengan Dun Can test ternyata pengaruh penyimpanan besar sekali baik dari kulit yang diawet kering maupun kulit garaman. Kulit yang disimpan 3 bulan kekuatan tariknya lebih jelek dibandingkan dengan kulit yang disimpan selama 2 bulan, sedangkan kulit yang disimpan selama 2 bulan kekuatan tariknya lebih jelek dibanding kulit yang disimpan 1 bulan.

\begin{tabular}{c|c|c}
\hline 3 bulan & 2 bulan & 1 bulan \\
\hline 1211,70 & 1464,40 & 1352,47 \\
\hline & & \\
\hline
\end{tabular}

3. Hasil pengujian kemuluran kulit (\%) kulit glase dari kulit yang diawet kering dan kulit garaman. 
abel *) : 3 Hasil pengujian kemuluran kulit (\%).

\begin{tabular}{|c|c|c|c|c|c|}
\hline \multicolumn{9}{|c|}{ Pengawetan } \\
\hline \multicolumn{3}{|c|}{ Kering } & & \multicolumn{3}{c|}{ Garaman } \\
\hline \multicolumn{3}{|c|}{ Replikasi } & \multicolumn{3}{|c|}{ Replikasi } \\
\hline 1 & 2 & 3 & 1 & 2 & 3 \\
\hline 45 & 72 & 62 & 50 & 48 & 52 \\
34 & 36 & 34 & 43 & 38 & 44 \\
32 & 34 & 36 & 38 & 40 & 38 \\
\hline
\end{tabular}

nalisa variance dari pengujian pertambahan panjang dapat diliat sebagai berikut :

nalisa variance dari pengujian kemuluran kulit glase.

\begin{tabular}{l|c|c|c|c|c}
\hline nalisa variance & df & SS & MS & F hit & $\begin{array}{c}\text { F tab/ } \\
0,05\end{array}$ \\
\hline $\begin{array}{l}\text { Kering garaman } \\
\text { ( pengawetan) }\end{array}$ & 1 & 12,4991 & 12,4991 & 0,4306 & 4,75 \\
Penyimpanan & 2 & 1144,4778 & 572,3889 & 19,7193 & 3,89 \\
Penyimpanan $X$ & 2 & 307,008 & 153,5004 & 4,2882 & 3,89 \\
garaman & 12 & 348,3228 & 29,0268 & & \\
Error & 12 & & \\
\hline
\end{tabular}

\section{Leterangan :}

Tidak ada perbedaan antara kulit yang diawet garam dan kulit yang diawet kering ( $P$ hit $P$ tab 0,05 ).

Ada pengaruh penyimpanan pada kulit yang diawet kering maupun kulit.yang diawet dengan garam.

Ada interaksi terhadap penyimpanan dan cara pengawetan (kering atau garaman).

*) Data dari : Studi perbandingan Mutu kulit jadi (Finished leather) yang Berasal dari kulit yang diawet dengan garam dan kulit yang diawet dengan sinar matahari.

Pengaruh penyimpanan di test dengan Dun Can test, ternyata nakin lama waktu penyimpanan ( 3 bulan).

cenulur kn kutitnyakin rendah dibandingkan dengan kulut yang disimpan 2 bulan.

Sedangkan kulit yang disımpan 2 bulan kemulurannya lebih rendah dibandingkan dengan kulit yang disimpan 1 bulan.

\begin{tabular}{c|c|c}
\hline 3 bulan & 2 bulan & 1 bulan \\
\hline 288 & 299 & 330 \\
\hline & & \\
\hline
\end{tabular}

\section{PEMBAHASAN}

Pekerjaan pendahuluan sebelum pengawetan kulit domba yang terpenting yaitu membersihkan sisa-sisa daging dan lemak yang masih menempel pada kulit.

Kulit domba pada umumnya telah bersih dari sisa-sisa daging, sehingga pekerjaan ini sering diabaikan.

Hal ini merupakan kesalahan yang umum dijumpai pada pengawet kulit.

Kebersihan kulit ikut menentukan kualitas hasil awetan dan juga kualitas kulit jadinya, seperti dinyatakan oleh O'Flaherty (1956) dan Soemitro (1972).

Dari hasil uji kekuatan tarik ternyata pada pengawetan dengan sinar matahari maupun dengan garam, ternyata tidak ada perbedaan tetapi ada pengaruh dari penyimpanan yaitu makin lama-penyimpanan makin kecil kekuatan tariknya.

Tetapi dilihat dari hasil keseluruhannya ternyata pengeringan kulit dengan sinar matahari dan garam kering sudah baik, karena memberikan hasil kekuatan tarik yang rata-rata lebih tinggi dari standar minimum (untuk kulit atasan $100 \mathrm{~kg} / \mathrm{cm}^{2}$ ).

Aten et al (1955) menyatakan bahwa pada pengawetan kulit dengan sinar matahari didaerah tropis, kulit domba dan kambing dapat kering dalam 3 jam atau kurang tergantung kelembaban dan kecepatan aliran udara.

Faktor-faktor ini pada waktu percobaan tidak diperhitungkan sehingga tidak diketahui berapa besar perbedaan dan sampai dimana pengaruhnya. 
endapat dengan Aten et al (1955) dimana pemilihan metoda gawetan kulit disesuaikan dengan keadaan setempat.

uk daerah yang sulit atau mahal garam dapat dilakukan pewetan dengan cara pengeringan.

a terbaik untuk daerah itu yaitu dipentang dibawah sinar ahari, hal itu disebabkan karena disamping lebih ekonomis mengurangi polusi garam terhadap lingkungan.

uk daerah yang curah hujannya tinggi, pengawetan kulit desinar matahari dan garam kering akan mengalami kesulitmaka sebaiknya dipakai pengawetan dengan menggunakan gabasah asal diperhatikan cara-cara pengawetannya.

gan memperhatikan ketentuan yang telah ada, dapat dikugi akibat buruk yang timbul pada waktu pengawetan dan pemanan kulit sehingga dapat dihasilkan kulit dengan kualitas t yang baik.

il-hasil dari kemuluran pada kulit jadi, ternyata tidak ada garuhnya dari cara pengawetan $(P=0,05)$ tetapi ada pengadari penyimpanan, makin lama kulit disimpan kemulurannya in rendah (tabel 3 ).

api hal ini memenuhi standar untuk kulit atasan, kemuluran simal adalah $60 \%$.

variasinya persentase kemuluran disebabkan karena perbedatebal tipisnya kulit glase.

ang variasi kemuluran dari tiap-tiap sampel pada lembar kudisebabkan karena perbedaan struktur serabut-serabut kulit. ini sesuai dengan pendapat Mandel dan Konegy (1966) wa perbedaan tebal sampel mempunyai pengaruh nyata terap kemuluran kulit.

aurut O'Flaherty (1956) makin besar kekuatan tarik akan sedikuti dengan kemuluran yang persentasenya lebih rendah api dalam penelitian ini terdapat penyimpangan-penyimpangantara kekuatan tarik dengan kemuluran seperti yang tercanpada tabel 2 dan tabel 3, hal ini disebabkan karena adanya Pedian struktur kulit.

\section{DAFTAR - PUSTAKA}

2. Aten. A.R.F., Innes E. Knew, 1955. Flaying and Curing of Hide and Skin as a. Rural Industry. F.A.O. of the United Nation Roms, Italy.

3. Balai Penelitian Kulit, 1962,. Kallidoscop kulit dari hewan hingga barang jadi. Course on flying and Curing. BPK. Yogyakarta.

4. Gustavson. K.H., 1956. The Chemistry and Reactivity of Collagen Academic Press Inc. Publisher. New York

5. Haryati., 1978. Studi Perbandingan cara pengawetan kulit domba mentah lokal dengan sinar matahari yang diawet dengan metoda yang baik terhadap kekuatan tarik dan kemuluran kulit samak jadi. Skripsi Sarjana Peternakan, Fakultas Peternakan. Universitas Gajah Mada.

6. Herwejnen W.B., 1956. Leather Technologie. Zuid Henderlansche Drukkery. H.V.S. Hertogenbosh.

7. Kulit Standar Indonesia, 1958. Balai Penelitian Kulit Yogyakarta

8. Mundi Utomo. B., 1976. Study Perbandingan Pengaruh Pengawetan Kulit Kambing Peranakan Ettawa jantan dengan sinar matahari dan garam basah terhadap kekuatan tarik kulit samak jadi. Skripsi Sarjana Peternakan, Fakultas Peternakan Universitas Gajah Mada.

9. O'Flaherty, Fred. W.T. Roddy and R.M. Lollar, 1956. The Chemistry and Technology of Leather Reinhold Publishing Corporation New York. Chapman and Hall, Ltd. London.

10. Studi perbandingan mutu kulit jadi (Finished leather) yang berasal dari kulit yang diawet dengan garam dan kulit yang di awet dengan sinar matahari, 1980, Balai Penelitian Kulit, Yogyakarta.

Ariningsih, L., 1973. "Pengaruh posisi dan lamanya pengeringan: sinar matahari terhadap kekuatan tarik dan kemuluran kulit kambing (Jaket) didaerah Istimewa Yogyakarta " Skrıpsı Sarjana Peter 